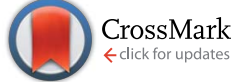

Cite this: RSC Adv., 2014, 4, 32658

\title{
Solid-phase peptide synthesis: an overview focused on the preparation of biologically relevant peptides
}

Received 20th March 2014 Accepted 18th July 2014

DOI: $10.1039 / \mathrm{c} 4 \mathrm{ra0} 2458 \mathrm{c}$

www.rsc.org/advances

\author{
Jose M. Palomo*
}

This review article highlights the strategies to successfully perform an efficient solid-phase synthesis of complex peptides including posttranslational modifications, fluorescent labels, and reporters or linking groups of exceptional value for biological studies of several important diseases. The solid-phase approach is the best alternative to synthesize these peptides rapidly and in high amounts. The key aspects that need to be considered when performing a peptide synthesis in solid phase of these molecules are discussed.

\section{Introduction}

Peptide synthesis has been, for more than a century, a significant synthetic approach in different areas such as protein chemistry and organic synthesis. Basically, the peptide formation goes through a repetitive amidation reaction between an amino group of one amino acid and the carboxylic group of a second one, the so-called peptide bond. In Nature these interactions between the twenty natural L-amino acids finally produce proteins. Fischer demonstrated that proteins are formed by amino acids and the peptide bond the interaction between them. He synthesized the first peptide (glycyl-glycine) and coined the name ${ }^{1}$ being considered the "father" of the peptide chemistry. Fischer's former student, Max Bergmann, introduced the carbobenzoxy group for the suitable reversible blocking group for the amine function which ushered in a new era. ${ }^{2}$ This general scheme was universally in use for years and it was very effective, for example, for the first synthesis of a peptide hormone by $d u$ Vigneaud in $1953 .^{3}$

Nowadays, one of the main applications of Fischer's discovery is to create semisynthetic proteins, ${ }^{4}$ natural or nonnatural ones, to aid in understanding biological processes ${ }^{5}$ (Fig. 1). In particular, the posttranslational modifications are essential for protein activation: phosphorylation for signal transduction, ubiquitination for proteolysis, attachment of fatty acids for membrane anchoring or glycosylation for extending protein half-life, targeting, and cell-cell interactions. ${ }^{6}$

The availability of a certain amount (milligrams) of these types of proteins (incorporating one or several posttranslational modifications) is mandatory for biological studies of a particular disease. However, the production of these target proteins in pure form is extremely complex or in some cases even

Departamento of Biocatalisis, Instituto de Catalisis (CSIC), Marie Curie 2, Cantoblanco 28049, Madrid, Spain. E-mail: josempalomo@icp.csic.es; Fax: +34915854760; Tel: +34-915854768 unfeasible by biochemical methods. Therefore, the work developed in peptide synthesis in the last years has permitted the successful preparation of tailor-made peptide sequences carrying out posttranslational changes, fluorescent labels, etc. $^{4 \boldsymbol{b}, 7, \mathbf{8}}$ These designed peptides have been linked to the engineered target protein afterwards - combining chemical and biological methods - to create natural proteins or semisynthetic non-natural analogues. ${ }^{7,8}$

The giant step for the evolution in the synthesis of larger and more complex peptides (or even proteins) ${ }^{9}$ has been made possible by the solid-phase. Bruce Merrifield was the pioneer of the idea of generating peptide bonds on an insoluble resin where a single cleavage step permits obtaining the desired peptide in solution. ${ }^{\mathbf{1 0}}$ This won him the Nobel Prize in Chemistry in $1984 .{ }^{11}$ The principle advantages of the chemistry on solid-phase are: (i) simplicity and speed (carrying out all the reactions in a single reaction vessel) and (ii) efficiency (avoiding the large losses which normally are encountered during the isolation and purification of intermediates, obtaining high yields of final products through the use of excess reactants).

The strategies developed for peptide synthesis in solution have been adapted to the solid phase, although in this type of the synthetic approach several issues such as the matrix swelling, type of linker groups, protecting groups in the amino acid residues, etc. must be considered. For the last twenty years, researchers have developed strategies to improve the performance in solid-phase peptide synthesis (SPPS). The application of microwave systems, the development of novel supports or novel activating groups are some of the emerging systems, which has been the focus of recent review articles. ${ }^{\mathbf{1 2 - 1 4}}$

In this article, a general view of peptide synthesis on solid phase and how this protocol has been successfully applied in the preparation of different important peptide sequences to study biological processes is emphasized. 


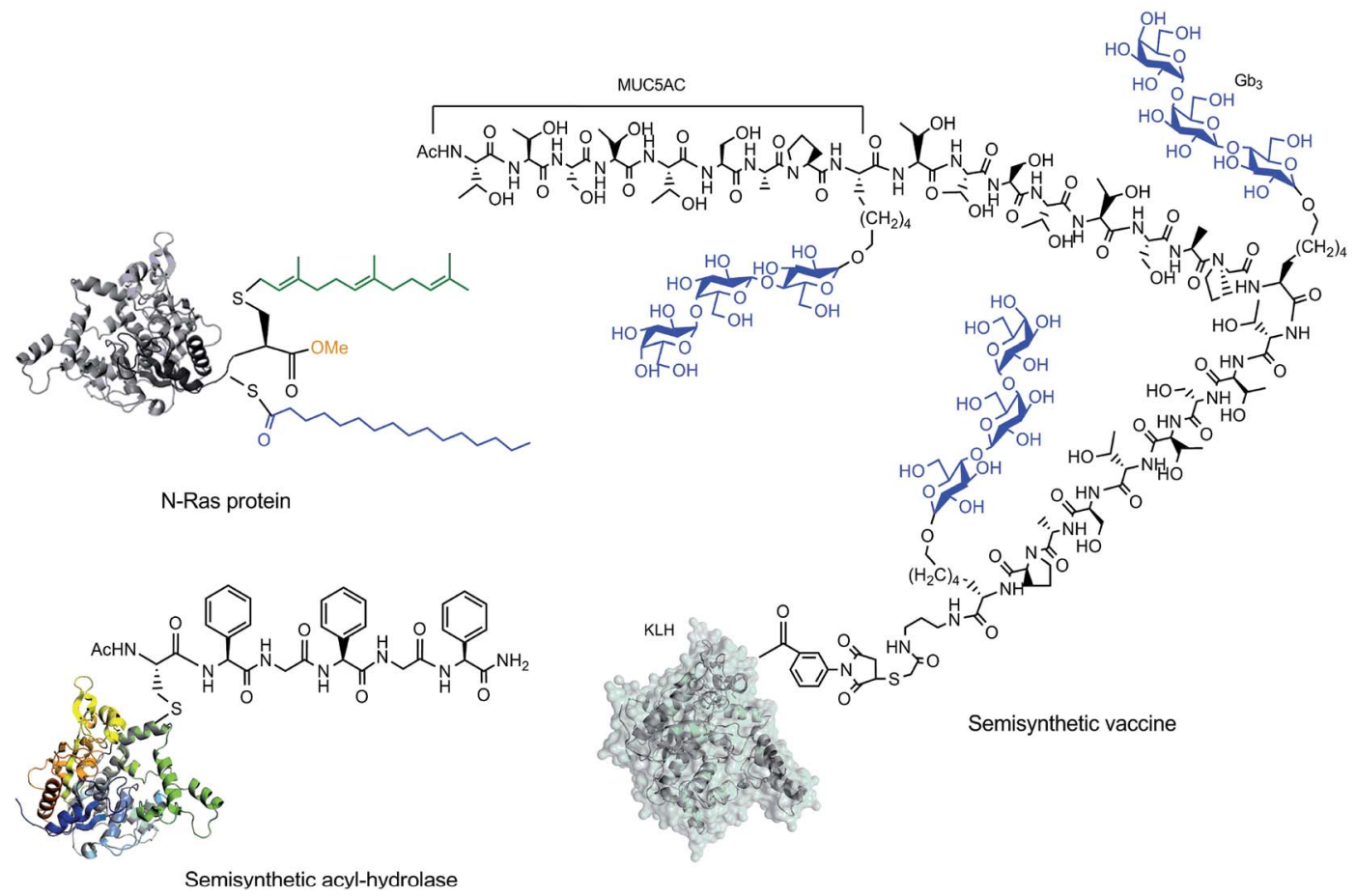

Fig. 1 Examples of semisynthetic biological proteins created by tailor-made peptide synthesis.

\section{Solid-phase peptide synthesis (SPPS)}

\subsection{Initial aspects of the peptide synthesis: $\mathbf{N}$-terminal amino acid protecting group}

The general process for synthesizing peptides on a resin starts by attaching the first amino acid (AA), from the C-terminal residue (carboxyl group), then proceeding with the peptide sequence construction to the N-terminal end. The amino acids are coupled to the supported peptide sequence by the alpha amino group and the reactive side chains are protected by a temporary protecting group. The carboxyl group of the corresponding amino acid must be activated for its coupling to the resin. Once the amino acid is attached, the resin is filtered and washed to remove byproducts and excess reagents. Next, the $\mathrm{N}$ $\alpha$-protecting group of the new couple AA is removed (deprotection process) and the resin is again washed to remove byproducts and excess reagents. Then, the next amino acid is coupled to the attached one. The cycle is repeated until the peptide sequence is complete. Then typically, all the protecting groups are removed, the resin is washed and the peptide is cleaved from the resin (Scheme 1).

A feature that defines the chemistry in the SPPS is the temporary protecting group in the amino acid $\mathrm{N}$-terminal amino group. The two most widely used are the tert-butoxycarbonyl (Boc) group (sensitive to acids such as trifluoroacetic acid (TFA)), ${ }^{10,15}$ and the fluoren-9-ylmethyloxycarbonyl (Fmoc) group (sensitive to bases such as piperidine) (Fig. 2).$^{\mathbf{1 6}}$

The Fmoc strategy is often preferred over the Boc strategy for routine synthesis, because the former can be removed under milder conditions than the latter, representing an orthogonal deprotection scheme considering that most of linkers and protecting groups of amino acid residues can be deprotected under acidic conditions. ${ }^{17}$ However, the application of an in situ neutralization protocol $^{15}$ has made the $B O C$ chemistry the selected strategy for increasing the efficiency in difficult or longer peptide sequences even implemented in automated synthesizers.

The coupling of the first amino acid represents a key step on an efficient SPPS, where a nearly quantitative yield is mandatory. The yield and scale of the solid-phase reactions are given

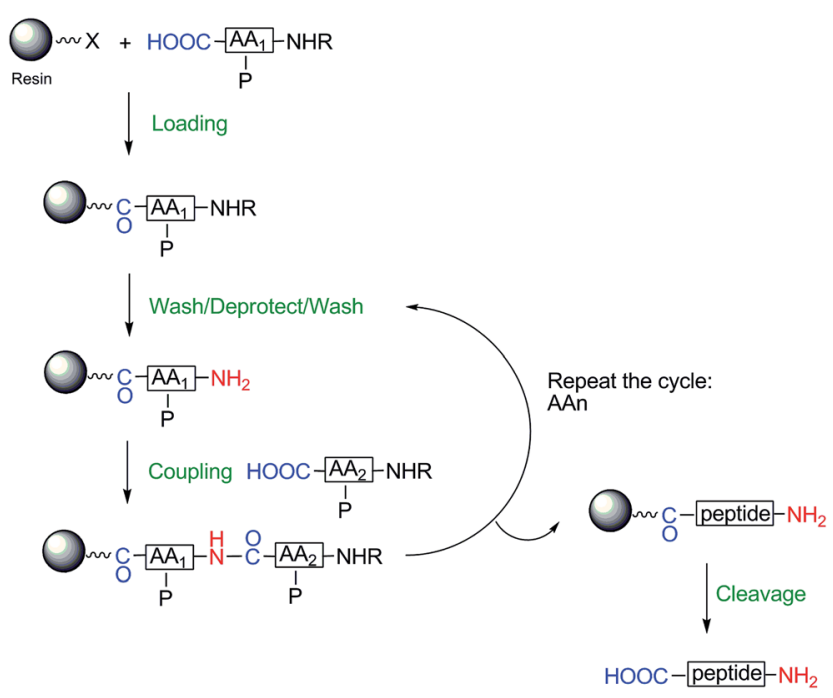

Scheme 1 General scheme of solid-phase peptide synthesis (SPPS). 
A

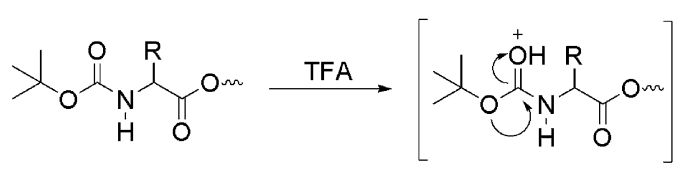

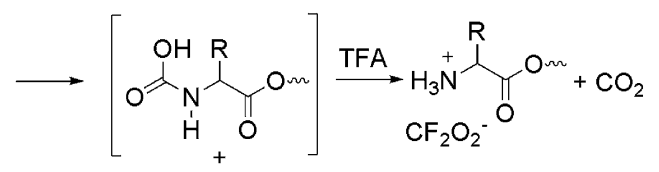

$\left[>_{+}\right] \stackrel{\mathrm{Nuc}}{\longrightarrow} \searrow_{\mathrm{Nuc}}+\Longrightarrow$

B
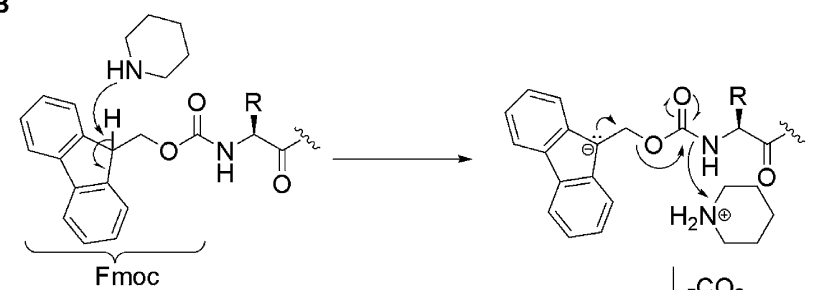

Fmoc

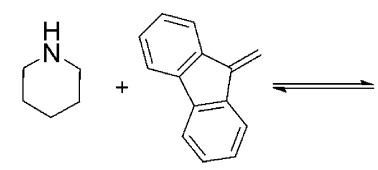

dibenzofulvene

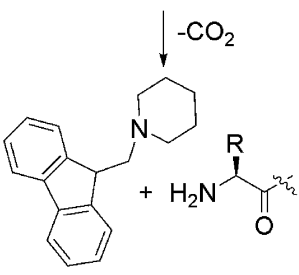

UV $301 \mathrm{~nm}$
Fig. 2 Deprotection scheme of the most popular protecting groups of $\alpha$-amino groups. (A) Boc deprotection mechanism. (B) Fmoc deprotection mechanism.

with respect to the amount of this first amino acid coupled onto the resin. Loading in the typical commercial resins goes from 0.3 to $2.5 \mathrm{mmol}_{\text {(reactive group) }}$ per $\mathrm{g}_{\text {(support) }}$.

The Fmoc-group has the advantage that can be used to monitor the first amino acid coupling to the resin by simple UV spectrophotometry analysis (Fig. 2).$^{18}$ Several milligrams of dry AA-resin can be treated with a solution of $20 \%$ piperidine in DMF for $30 \mathrm{~min}$, and then (not later) this solution (3 $\mathrm{mL}$ ) can be used for the monitoring of the UV absorbance at $301 \mathrm{~nm}$ of the dibenzofulvene-piperidine adduct formed (Fig. 2). The same piperidine solution must be used as a reference for the previous calibration of the UV spectrometer to zero. The loading can be calculated by using this equation: ${ }^{18}$ loading $\left(\mathrm{mmol} \mathrm{g}^{-1}\right)=$ $\mathrm{Abs}_{\text {sample,301nm }} \times 0.4^{*},\left({ }^{*}\right.$ based on $\left.\varepsilon=6000 \mathrm{M}^{-1} \mathrm{~cm}^{-1}\right) ; 3 \mathrm{~mL}$ deblocking solution, $5 \mathrm{mg}$ resin, UV cell $10 \mathrm{~mm} .^{18}$

\subsection{Monitoring of coupling and capping}

Monitoring of the coupling steps is critical in the successful peptide synthesis. Different tests have been developed for that purpose. ${ }^{19-21}$

The Kaiser test is historically and today one of the most used. ${ }^{19}$ It is a qualitative test for the presence or absence of free primary amino groups, and it can be a useful indicator of the completeness of a coupling step. The test is based on the reaction of ninhydrin ${ }^{19}$ with primary amines, which gives a

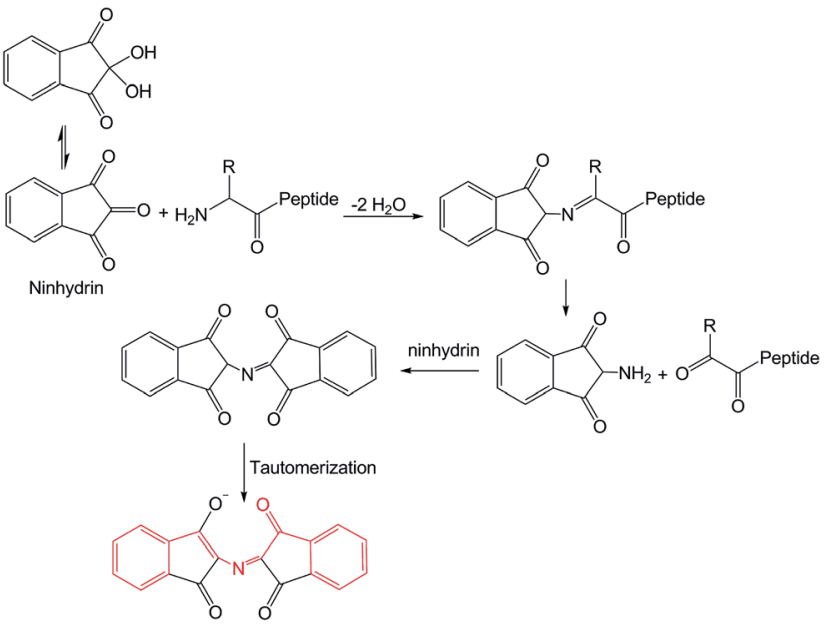

Scheme 2 Reaction mechanism of peptides with ninhydrin (Kaiser test).

characteristic dark blue color (Scheme 2). For determining the presence of secondary amine the choranil/acetaldehyde test ${ }^{21}$ is the most adequate.

In addition, the tests require minimal amounts of analyte and it is completed within a few minutes. The testing protocol should be followed carefully. Excess heat can cause loss of Fmoc protecting groups through reaction with pyridine (contained in the test reagents), resulting in a false positive result. If the monitoring test indicates the presence of unreacted amine following a coupling reaction, a second coupling step or the modification of the coupling conditions should be performed. If it is still present after this treatment, the capping of the amino group by the reaction with acetic anhydride should be used.

\subsection{Selection of the resin material and swelling properties}

Polystyrene (PS) is the most common core resin in solid-phase chemistry. Most polystyrene supports contain $1 \%$ or $2 \%$ divinylbenzene (DVB) as a cross linking agent, being insoluble in all common solvents. Typically, these resins are small and spherical beads of two different sizes: 100-200 mesh (75-150 microns) and 200-400 mesh (35-75 microns).

Polyamines and polyethyleneglycols (PEG)-PS resins have been applied later to perform the synthesis of polar substrates and even in water solution. ${ }^{22}$ ChemMatrix® resin, a totally PEG resin, has been recently developed for the synthesis of many long and complex peptides, ${ }^{23}$ with a higher loading capacity than other PEG resins (from $0.2-0.3 \mathrm{mmol} \mathrm{g}^{-1}$ to $0.6-0.7 \mathrm{mmol} \mathrm{g}^{-1}$ ) and allowing the use of almost any kind of solvents, even water.

The swelling of the polystyrene material in organic solvents is an important issue. ${ }^{\mathbf{1 0}, 11}$ This phenomenon has a very high influence in the diffusion and accessibility of the reagents into the core of the polymer and therefore to the synthetic efficiency. Thus, the typical swelling factor for a 1\% DVB cross-linked PS resin goes from 5-6 times in THF, toluene, $\mathrm{CH}_{2} \mathrm{Cl}_{2}$, or dioxane, 4 times in DMF, 2 times in $\mathrm{EtOH}$ or $\mathrm{CH}_{3} \mathrm{CN}, 1.6$ times in $\mathrm{MeOH}$ up to no swelling in water. ${ }^{24}$ These swelling factors depend on the sort of resin. ${ }^{25}$ For example a resin with $2 \%$ DVB cross-linking 
Swells only 2 to 4 times its original volume in $\mathrm{CH}_{2} \mathrm{Cl}_{2}$ (Fig. 3A). The addition of $\mathrm{Et}_{2} \mathrm{O}$ to a $\mathrm{CH}_{2} \mathrm{Cl}_{2}$-swollen resin causes the contraction of the beads size in more than 2 times (Fig. 3B). ${ }^{25} \mathrm{An}$ incubation of the resin in the corresponding solvent for $1 \mathrm{~h}$ stirring slowly is enough to complete the swelling.

From a classic peptide synthesis, Merrifield observed that the swelling of the unloaded resin was higher in $\mathrm{CH}_{2} \mathrm{Cl}_{2}$ than in DMF. However, the swelling factor gradually decreased in this solvent as the peptide content increased, and being increased in DMF (Fig. 3C). ${ }^{24}$ However, $\mathrm{CH}_{2} \mathrm{Cl}_{2}$ is not compatible with piperidine, which is used to remove the Fmoc group, because of the formation of piperidine hydrochloride, and it is not a good solvent for Fmoc amino acids and some coupling reagents. Therefore, in a peptide synthesis using a PS resin, $\mathrm{CH}_{2} \mathrm{Cl}_{2}$ is normally the major solvent at the beginning and sometimes as cleavage solvent. Mixtures of DMF- $\mathrm{CH}_{2} \mathrm{Cl}_{2}$ are used in SPPS using PS resin in the first coupling whereas DMF is the main solvent after several couplings (Fig. 3C). However, PEG resins swell properly in a large variety of solvent, even acetonitrile. ${ }^{26}$
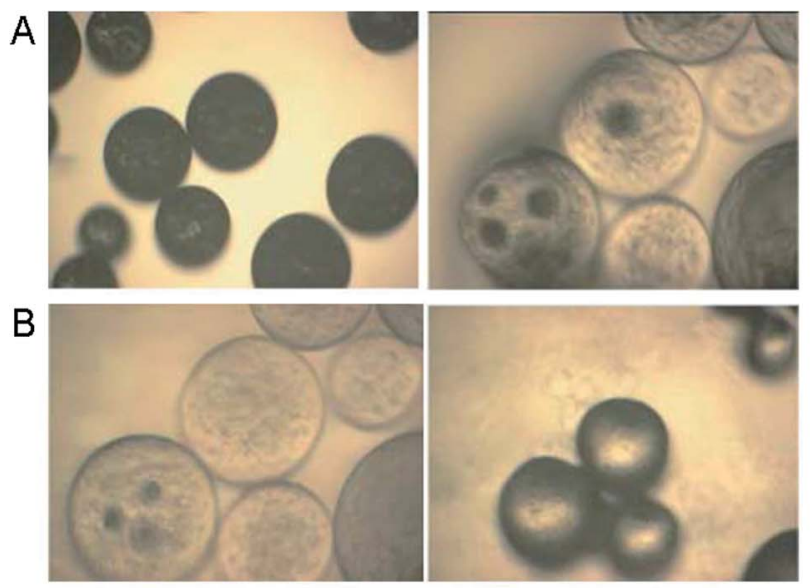

C

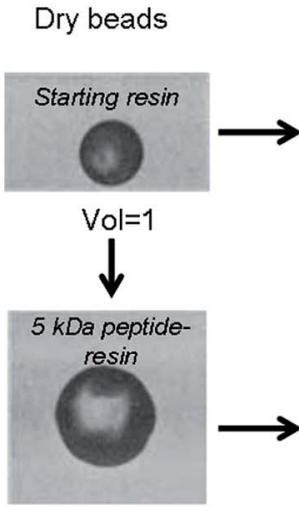

Vol=5
Swollen beads

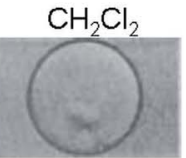

$\mathrm{Vol}=6.2$

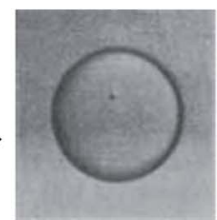

Vol $=11.7$

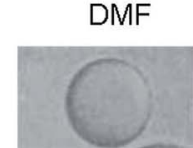

$\mathrm{Vol}=3.3$

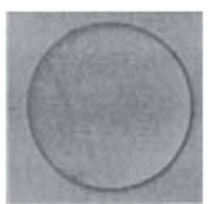

$\mathrm{Vol}=26.3$
Fig. 3 Photographs of swelling effect on resin beads by the solvents. (A) (Left to right) The expansion of polystyrene beads 2\% DVB crosslinked in $\mathrm{CH}_{2} \mathrm{Cl}_{2}$. (B) (Left to right) The contraction of pre-swollen polystyrene beads in $\mathrm{Et}_{2} \mathrm{O}$. This figure is reprinted with permission. ${ }^{25}$ (C) Expansion of polystyrene beads 1\% DVB crosslinked and peptide-Ps resin showing relative dimensions before and after swelling (adapted from ref. 24).
PS-resins chemically functionalized by methylchloride (Merrifield resin), bromide, hydroxy methyl (HM), aminomethyl (AM), carboxylic acid or aldehyde are commercially available. Using the Merrifield resin, the first amino acid is directly coupled without previous activation, although the cleave condition involves the hazards and inconvenience of working with HF, high pressure gas manifold, the inability to use glassware, and a highly poisonous reagent. ${ }^{10} \mathrm{HM}$ and AM resins have long been used in solid-phase peptide synthesis as a core resin to which various linkers could be attached through a stable amide bond.

\subsection{Linkers for SPPS}

Linkers are the chemical units used to attach an amino acid to a resin bead for performing molecule growing in solid phase. The nature of the linker determines the chemistry to be used, and especially the conditions under the products can be cleaved from the resin. A wide variety of linkers for polystyrene core resin have been developed in the last years. ${ }^{15}$ Table 1 summarizes some of the most popular resins for SPPS (commercially available) with different linkers with the particular cleavage conditions and the final C-terminal functionalization obtained in the synthesized peptide in each case. ${ }^{17,27-30}$ Most of them use acidic conditions for the cleavage, yielding peptides containing a carboxylic acid (e.g. Wang resin) or an amide (e.g. MBHA resin) at the C-terminus. Hydrazides or sulfonamides attach to the resin allow for the release of the peptide equipped with a different functional group by orthogonal mild cleavage conditions (Table 1). Albericio and coworkers have recently developed a new resin for SPPS with a better performance compared with the traditional Wang resin..$^{31}$ This is based on the use of a linker with two features: methoxy groups as the only activating groups of the phenyl ring and a copper(I)-catalyzed click chemistry reaction to anchor it to the solid support. ${ }^{31}$

\subsection{Orthogonal strategy of protecting groups}

The correct choice of the protecting groups of the side-residues in the amino acids represents a crucial step before starting the peptide synthesis. $^{32}$

Acidic labile protecting groups are the most used in Fmoc chemistry (basic labile). Actually, a repertoire of different protecting groups for each amino acid exists, and the deprotection conditions depend on the specific amino acid. Table 2 shows a summary of some of the most popular AA protecting groups and the corresponding deprotection conditions. ${ }^{32}$

For example, protecting groups stable in acidic and basic conditions such as Alloc in Lys or thio ${ }^{t} \mathrm{Bu}$ in Cys show a different deprotecting mechanism, Pd catalysis or thioldisulfide exchange respectively (Table 2).

\subsection{Activation of the carboxyl group of the amino acids}

The addition of a coupling reagent to activate the $\alpha$-carboxyl group of the amino acid is necessary for a rapid and quantitative amide bond formation. Fig. 4 shows a list of the most used activating groups and activation mechanism. ${ }^{13}$ 
Table 1 Different resins for SPPS

\begin{tabular}{|c|c|c|c|}
\hline Resin name & Resin structure & Cleavage conditions & Peptide product \\
\hline Wang resin & & $90-95 \%$ TFA in $\mathrm{CH}_{2} \mathrm{Cl}_{2} 1-2 \mathrm{~h}$ & Acid \\
\hline Rink acid resin & & $\begin{array}{l}1-5 \% \text { TFA in } \mathrm{CH}_{2} \mathrm{Cl}_{2} \\
5-15 \text { min or } 10 \% \mathrm{AcOH} \\
\text { in } \mathrm{CH}_{2} \mathrm{Cl}_{2}, 2 \mathrm{~h}\end{array}$ & Acid \\
\hline HMPB resin & & $1 \%$ TFA in $\mathrm{CH}_{2} \mathrm{Cl}_{2} 2-5 \mathrm{~min}$ & Acid \\
\hline SASRIN resin & & $1 \%$ TFA in $\mathrm{CH}_{2} \mathrm{Cl}_{2}$ 5-10 min & Acid \\
\hline Rink amide resin & & $50 \%$ TFA in $\mathrm{CH}_{2} \mathrm{Cl}_{2} 1 \mathrm{~h}$ & Amide \\
\hline Sulfonamide resin & & $\begin{array}{l}\text { 1. } \mathrm{ICH}_{2} \mathrm{CN} / \mathrm{DIPEA} / \mathrm{NMP}, 24 \mathrm{~h} \\
\text { 2. Nucleophile, DMAP, } 24 \mathrm{~h}\end{array}$ & $\begin{array}{l}\text { Acid, ester, thioester, } \\
\text { amide, etc. }\end{array}$ \\
\hline HMBA resin & & $\begin{array}{l}\mathrm{NaOH}, \mathrm{N}_{2} \mathrm{H}_{4}, \mathrm{NH}_{3} \text { in } \\
\mathrm{MeOH} 24 \mathrm{~h} \\
\mathrm{ROH} \\
\mathrm{LiBH}_{4}\end{array}$ & $\begin{array}{l}\text { Acid, hydrazide, amide } \\
\text { Ester } \\
\text { Alcohol }\end{array}$ \\
\hline PEGA-BAL resin & & TFA-TFMSA (19: 1) & Acid \\
\hline
\end{tabular}

Dicyclohexylcarbodiimide (DCC) was first used by Merrifield $^{11}$ as the simplest and most popular reagents for carboxyl activation. The reaction was performed $\mathrm{CH}_{2} \mathrm{Cl}_{2}$ or $\mathrm{DMF},{ }^{11}$ although dicyclohexylurea, a byproduct formed from DCC, is nearly insoluble in most organic solvents. Therefore, DCC is very useful in solution phase reactions, but is not appropriate for reactions on resin. Diisopropylcarbodiimide (DIC) is used instead in solid phase synthesis since the urea byproduct remains in solution. However, a partial racemization process has been observed in this activation, because the $O$-acylisourea formed is very reactive causing loss of chiral integrity of the amino acid. The addition of 1-hydroxybenzotriazole (HOBt) has 
Table 2 Protecting groups in the aminoacids residues

\begin{tabular}{|c|c|c|c|}
\hline Amino acid & Protecting group & Structure & Deprotection conditions \\
\hline & Pmc & & 90-95\% TFA in $\mathrm{CH}_{2} \mathrm{Cl}_{2}, 2-4 \mathrm{~h}$ \\
\hline & $\mathrm{Pbf}$ & & $\begin{array}{l}90 \% \text { TFA in } \mathrm{CH}_{2} \mathrm{Cl}_{2} / \mathrm{TIS}, 1 \mathrm{~h} \text { (longer times in multiple } \\
\text { Arg containing peptides) }\end{array}$ \\
\hline Asp/Glu & $\mathrm{O}^{t} \mathrm{Bu}$ & & $90 \%$ TFA in $\mathrm{CH}_{2} \mathrm{Cl}_{2}, 30 \mathrm{~min}$ \\
\hline \multirow[t]{2}{*}{ Asn/Gln } & Trt & & $90 \%$ TFA in $\mathrm{CH}_{2} \mathrm{Cl}_{2}, 30-60 \mathrm{~min}$ \\
\hline & Mtt & & $1 \%$ TFA in $\mathrm{CH}_{2} \mathrm{Cl}_{2}, 60 \mathrm{~min}$ \\
\hline & Trt & & $90 \%$ TFA in $\mathrm{CH}_{2} \mathrm{Cl}_{2}, 30 \mathrm{~min}$ \\
\hline & $\mathrm{S}^{t} \mathrm{Bu}$ & & TFMSA \\
\hline \multirow[t]{3}{*}{ His } & Mtt & & $15 \%$ TFA in $\mathrm{CH}_{2} \mathrm{Cl}_{2}, 1 \mathrm{~h}$ \\
\hline & Trt & & $90 \%$ TFA in $\mathrm{CH}_{2} \mathrm{Cl}_{2}, 30 \mathrm{~min}$ \\
\hline & Boc & & $90 \%$ TFA in $\mathrm{CH}_{2} \mathrm{Cl}_{2}, 30 \mathrm{~min}$ \\
\hline \multirow[t]{3}{*}{ Lys/Orn } & Boc & & $90 \%$ TFA in $\mathrm{CH}_{2} \mathrm{Cl}_{2}, 30 \mathrm{~min}$ \\
\hline & Mtt & & $1 \%$ TFA in $\mathrm{CH}_{2} \mathrm{Cl}_{2}, 30 \mathrm{~min}$ \\
\hline & Alloc & Ö & $\mathrm{Pd}\left(\mathrm{PPh}_{3}\right)_{4}(5 \mathrm{~mol} \%), \mathrm{PhSiH}_{3}, \mathrm{THF} / \mathrm{CH}_{3} \mathrm{OH}, 12 \mathrm{~h}$ \\
\hline \multirow[t]{2}{*}{ Ser/Thr } & ${ }^{t} \mathrm{Bu}$ & & $90 \%$ TFA in $\mathrm{CH}_{2} \mathrm{Cl}_{2}, 30 \mathrm{~min}$ \\
\hline & Trt & & $1 \%$ TFA in $\mathrm{CH}_{2} \mathrm{Cl}_{2}, 2 \mathrm{~h}$ \\
\hline \multirow[t]{2}{*}{ Trp } & Boc & & $95 \%$ TFA in $\mathrm{CH}_{2} \mathrm{Cl}_{2}, 1 \mathrm{~h}$ \\
\hline & Alloc & & $\begin{array}{l}\mathrm{Pd}\left(\mathrm{PPh}_{3}\right)_{4}(5 \mathrm{~mol} \%) \text {, methylanilin, } \\
\text { DMSO-THF-0.5 M HCl (1: } 1: 0.5), 8 \mathrm{~h}\end{array}$ \\
\hline \multirow[t]{3}{*}{ Tyr } & Trt & & $2 \%$ TFA in $\mathrm{CH}_{2} \mathrm{Cl}_{2}$ \\
\hline & ${ }^{t} \mathrm{Bu}$ & & $35 \%$ TFA in $\mathrm{CH}_{2} \mathrm{Cl}_{2}$ \\
\hline & Alloc & & $\mathrm{Pd}\left(\mathrm{PPh}_{3}\right)_{4}(5 \mathrm{~mol} \%), \mathrm{PhSiH}_{3}, \mathrm{THF} / \mathrm{CH}_{3} \mathrm{OH}$ \\
\hline
\end{tabular}

minimized this problem, because the corresponding benzotriazolyl ester is less reactive, more stable and less prone to racemization than the $O$-acylisourea.

In this way, considering the problems using carbodiimides during the coupling, onium (aminium/uronium and phosphonium) salts were developed. ${ }^{12}$ The most widely used salts are $N$ -
[(1H-Benzotriazol-1-yl)(dimethylamino)-methylene $]-N$-methylmethanaminium hexafluorophosphate $N$-oxide (HBTU), Benzotriazol-1-yl- $N$-oxy-tris(pyrrolidino)phosphonium hexafluorophosphate (PyBOP) or $N$-\{(Dimethylamino)- $1 H-1,2,3$-triazolo [4,5-b]-pyridino-1-ylmethylene $\}-N$-methylmethan-aminium hexafluorophosphate (HATU), similar to HBTU but reacts faster with 
A

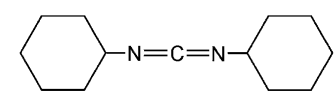

DCC<smiles>CN(C)C(N(C)C)n1n[n+]([O-])c2ccccc21</smiles>

HBTU<smiles>Cn1cnc2ccccc21</smiles><smiles>COP(N1CCCC1)N1CCCC1</smiles>

РувоР

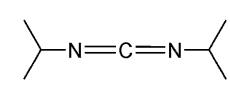

DIC

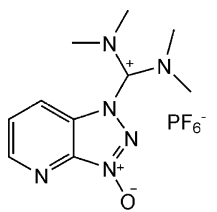

HATU

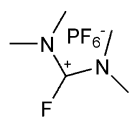

TFFH
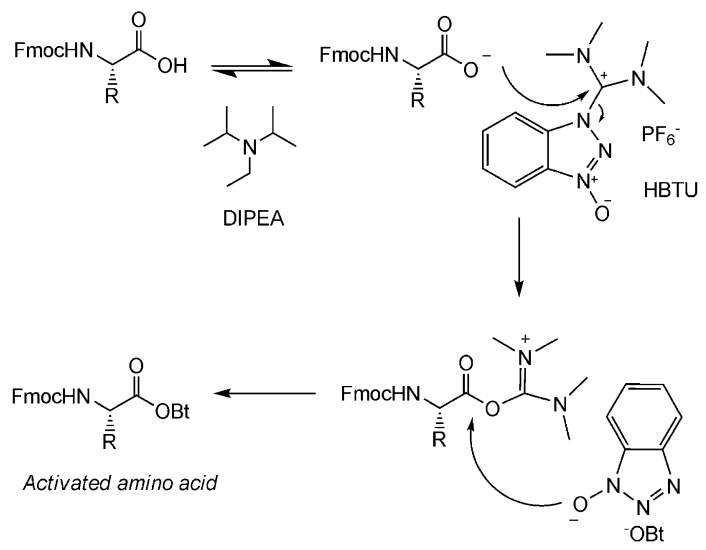

Fig. 4 (A) Traditional coupling reagents for carboxylic acid activation. (B) HBTU/HOBt amino acid activation mechanism.

less epimerization during coupling (Fig. 4)..$^{12}$ The coupling with these salts must be combined with HOBt in the presence of a base, usually $N, N$-diisopropylethylamine (DIPEA). Tetramethylfluoroformamidinium hexafluorophosphate (TFFH) generates acid fluorides in situ which are very convenient for the incorporation of hindered amino acids. ${ }^{12,26}$ New coupling reagents based on the Oxyma scaffold, such as the uronium salt 1-cyano2-ethoxy-2-oxoethylidenaminooxy dimethylamino-morpholinocarbenium hexafluorophosphate (COMU), ${ }^{14,33}$ has been developed showing in some cases several advantages over classic benzotriazole-based reagents.

\subsection{Specific considerations in SPPS}

Particular conditions of the coupling must be used, for example, for cysteine due to the high degree of racemization. Then, the solvent for the coupling must be $\mathrm{CH}_{2} \mathrm{Cl}_{2}-\mathrm{DMF}(1: 1)$, without pre-activation of the amino acid, using mainly collidine (trimethylpyridine, TMP) (5 equiv.), a weaker base than piperidine. These experimental conditions have been of particular interest in the coupling of farnesylated cysteine to the resin as first amino acid, such as in lipopeptide synthesis. ${ }^{27,28}$
When the Fmoc deprotection is slow or incomplete, piperidine can be replaced by 1,8-diazabicyclo[5.4.0]undec-7-ene $(\mathrm{DBU})(1 \%(\mathrm{v} / \mathrm{v}))$ in DMF $(2 \times 30 \mathrm{~s})$. DBU, a non nucleophilic base, can improve the deprotection yield and thus the yield of the desired peptide. This base substitution can be also performed in the case of the presence of thioesters in the peptide sequence, such as the palmitoylated peptides. ${ }^{27}$

Aspartamide side products formation, for example when using DBU, can be avoided using Fmoc-Asp(OMpe)-OH for amino acid coupling with the addition of $5 \%$ of formic acid to the standard Fmoc cleavage agent solution. ${ }^{34}$

Aggregation effects can be observed in some peptide sequences by chain elongation. The use of PEG-PS resin, DMF and some additives such as detergents $(1 \%(\mathrm{v} / \mathrm{v}))$ are some of the alternatives to reduce the problem. Particularly Ala, Ile, Met and Lys are the most prone to aggregation, whereas Pro, Arg or His have low levels of aggregation.

The protecting groups of amino acid residues must be removed once the peptide sequence is finished. This part can be performed before the cleavage, the last step, or at the same time using the conditions described in Table 2 . Finally the peptide cleavage from the solid-support is performed according to the conditions requested for the corresponding linker (Table 1).

\section{Synthesis of tailor-made peptides including post translational modifications on solid phase}

Post-translational covalent modification phenomenon is essential for protein activation in Nature which is critical for the regulation of interactions with other proteins and small molecules. ${ }^{6,35}$ Between the different types of protein modifications, ${ }^{35}$ it can be emphasized: (i) lipidation (palmitoylation, myristoylation) and prenylation (farnesylation, geranylation), ${ }^{36}$ for membrane anchoring involved in vesicular transport and cell signaling, growth, and differentiation, (ii) glycosylation, for extending protein half-life, targeting, and cell-cell interactions ${ }^{37}$ and (iii) phosphorylation, for signal transduction ${ }^{38}$ (the most relevant and extended in Nature) (Fig. 5).

Particularly, post-translational modifications of polypeptide chains often occur at multiple sites or in tandem cascades, crucial for biological function. For example, Abl tyrosine kinase is found phosphorylated at eleven different sites (more than $4 \times$ $10^{7}$ possible phosphorylated isoforms for one protein) ${ }^{38}$ spread over the different catalytic and regulatory domains of the protein. The Ras protein superfamily, important proteins present in around $30 \%$ of all human cancers, suffer the consecutive four different post-translational modifications to be biologically active. ${ }^{36}$ Mucins, epithelial surface proteins, are heavily glycosylated with complex linked $O$-oligosaccharides involved in protection and control of the cell surface. ${ }^{39}$ However, the isolation of these modified proteins for biosynthesis usually reveals the presence of heterogeneous mixtures which make the investigations of their role in biological processes quite difficult. ${ }^{40}$ In particular fully lipid-modified parts of lipoproteins are often not accessible in their completely lipidated form of gene- 


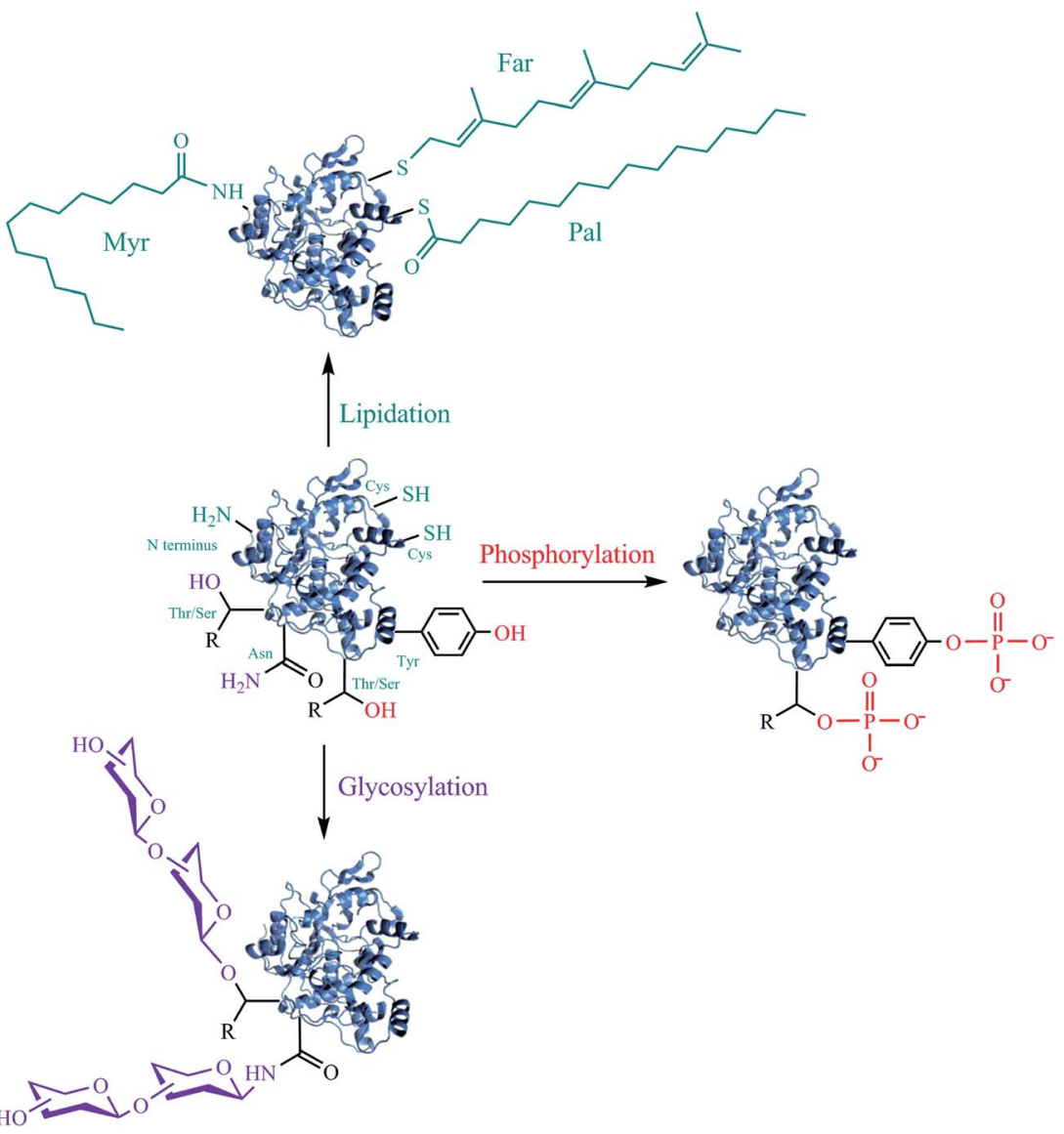

Fig. 5 Post-translational protein modifications. Pal: palmitoyl, Myr: myristoyl, Far: farnesyl.

technological methods. The pure homogenous modified proteins need to be prepared by semisynthesis from suitably functionalized synthetic peptides and expressed protein parts. Tailor-made peptides incorporating the specific posttranslational modification/s, that embody the characteristic modified amino acid sequences of their parent proteins, have proven to be efficient reagents and chemical tools for chemicalbiological, biochemical, biophysical, structural-biological and cell-biological studies.

For the efficient and rapid synthesis of these peptide conjugates, a flexible solid-phase technique is required. At this stage, a SPPS strategy that proceeds with preparative viable overall yields must be selected, considering these additional chemical groups incorporated on the amino acids, especially for peptides including multiply post-translational changes that represent the fully modified protein.

Therefore, taking into account all the aspects about the solid phase synthesis described above, the selected technique would feature very mild, preferably neutral conditions (e.g. the sensitivity of lipidated chains to acid or basic conditions), to allow for the introduction of additional reporter groups (e.g., fluorophores) and tags (e.g., for coupling to expressed proteins), and allow for the release of the peptides from the solid support as carboxylic acids or esters (depending on the precise structure of the natural blueprint), or equipped with a different functional group at the $\mathrm{C}$ terminus.

\subsection{Phosphopeptides}

Natural modification of proteins by phosphorylation occurs in tyrosine, threonine and serine residues being the most relevant the first one.

Phosphopeptides can be synthesized by two different approaches: ${ }^{41}$

(i) Direct phosphorylation of the amino acid on resin (after amino acid coupling or after peptide is synthesized) e.g. using diarylphosphorochloridate or phosphoramidite reagents. Selectively orthogonal removable protecting groups on the serine, threonine or tyrosine residues to be phosphorylated must be used.

(ii) The use of protected, phosphorylated amino acid building blocks in the SPPS.

The second option seems to be in general the best choice, avoiding side reactions such as the oxidation step of $\mathrm{P}^{\mathrm{III}}$ (e.g. oxidation of cysteine, methionine or tryptophan residues) or the formation of $\mathrm{H}$-phosphonates ${ }^{\mathbf{4 1}}$ in the direct peptide phosphorylation (Fig. 6A).

The feasibility of chemical synthesis of phosphorylated peptides by Fmoc-SPPS was greatly enhanced by the introduction of the monobenzyl protecting group for the phosphate 
A<smiles>NC(=O)C(Cc1ccc(OP(=O)(O)O)cc1)NC(=O)O</smiles>

B

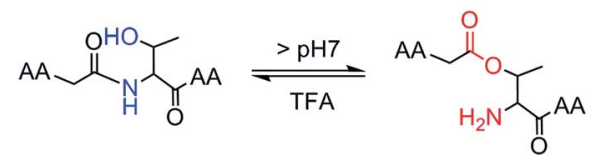

Fig. 6 Problems in phosphopeptides synthesis. (A) I: phosphate, II: phosphonate. (B) $\mathrm{N} \rightarrow \mathrm{O}$-acyl migration.

group. ${ }^{41,42}$ This minimized $\beta$-elimination of the phosphate group and an $\mathrm{N}$-O-acyl migration at threonine residues (Fig. 6B) ${ }^{42}$ making Fmoc-based synthesis of phosphopeptides the preferred synthesis strategy. For example the use of Fmoc$\operatorname{Tyr}(\mathrm{PO}(\mathrm{OBzl}) \mathrm{OH})$ avoids this problem and allows the improvement of both purity and yield of phosphopeptides. These OBzl groups are cleaved in similar conditions to the cleavage in Wang resin (Table 1). PEGA resin has been successfully used in the synthesis of this type of peptides. In particular, Jensen and coworker synthesized a set of different phosphopeptides on preloaded acryloylated $O, O^{\prime}$-bis(2-aminopropyl)polyethylene glycol copolymer (PEGA) with the 4-formylphenoxyacetic acidderived backbone amide linker (BAL). ${ }^{43}$ This solid-supported peptides were used for pull-down and analysis of the affinity profile of the integrin-linked kinase associated phosphatase (ILKAP), a member of the protein phosphatase 2C (PP2C) family.

\subsection{Glycopeptides}

Glycosylation can occur in asparagine ( $N$-glycosylation), serine or threonine (O-glycosylation). The incorporation of the sugar moiety into the peptide sequence is a crucial step in the chemical synthesis of glycopeptides. This phenomenon can be performed after amino acid coupling directly on the resin or by using glycosylated amino acid building blocks prepared in solution. ${ }^{\mathbf{4 4 - 4 6}}$ The first strategy makes necessary the use of a specific linker stable to acidic and base conditions and the saccharide incorporation requires the use of an excess of activated sugar due to the low reactivity of the side chain hydroxyls. In the case of $\mathrm{N}$-glycosylated peptides, the coupling of glycosylamine and an aspartic acid-containing peptide is severely hampered by the formation of intramolecular aspartimide.

Therefore, currently the most general synthetic methodology applied for glycopeptides synthesis on the solid-phase is the second strategy, the use of glycosylated-amino acid building blocks. ${ }^{46}$

Additionally, the complexity and liability conferred by the carbohydrate group must be considered. ${ }^{45}$ The glycosidic bond of the saccharides are acid labile (e.g. with strong acid as hydrogen fluoride), and the $O$-linked glycopeptide can undergo

$\beta$-elimination upon treatment with strong bases (Fig. 7). However, the former is stable to treatment with concentrated TFA at short times, especially when the hydroxyl groups of sugar are protected as esters. The latter is stable to bases, e.g. morpholine, piperidine, DBU, that are commonly used to remove the Fmoc protecting group for SPPS (Fig. 7).

Thus, these labile characters limit the variety of protecting groups that can be applied for glycopeptide synthesis. ${ }^{\mathbf{4 0 , 4 1}}$ Considering the assumptions discussed above, protecting groups such as Trityl or Mtt (4-methytrityl) (deprotected by low acidic conditions, see Table 2) would be the best choice for amino acid residues.

The hydroxyl groups of the oligosaccharide moiety are generally protected by acetyl groups in order to avoid esterification of sugar hydroxyl groups during the elongation of the peptide chain and stabilize the $O$-glycosidic linkages during cleavage with TFA. The $O$-acetyl-groups can be removed by treatment with dilute sodium methoxide in methanol, hydrazine hydrate or saturated ammonia in methanol. These reaction conditions, if carefully monitored, will not affect the glycopeptide structure and they are compatible to high concentrations of TFA. $^{45}$

Thus for the SPPS of glycopeptides using the glycosylated amino acid building blocks, Wang, Rink-amide, Sasrin or 2chlorotrityl chloride resin have been generally used. ${ }^{45}$

These strategies of the solid phase, for example using the chlorotrityl resin, has been successfully applied in the synthesis of glycopeptides mimics of mucin sequences of epithelial tumor cells, one of the most promising tumor-associated antigens. ${ }^{\mathbf{4 4 - 4 7}}$

Very recently, a new strategy using hydrazine linker into the solid-phase synthesis of $O$-linked glycopeptides for the first time combined with the use of a fluorous-tagged glycosyl donor permitted the synthesis of the target molecules in a high purity,

A
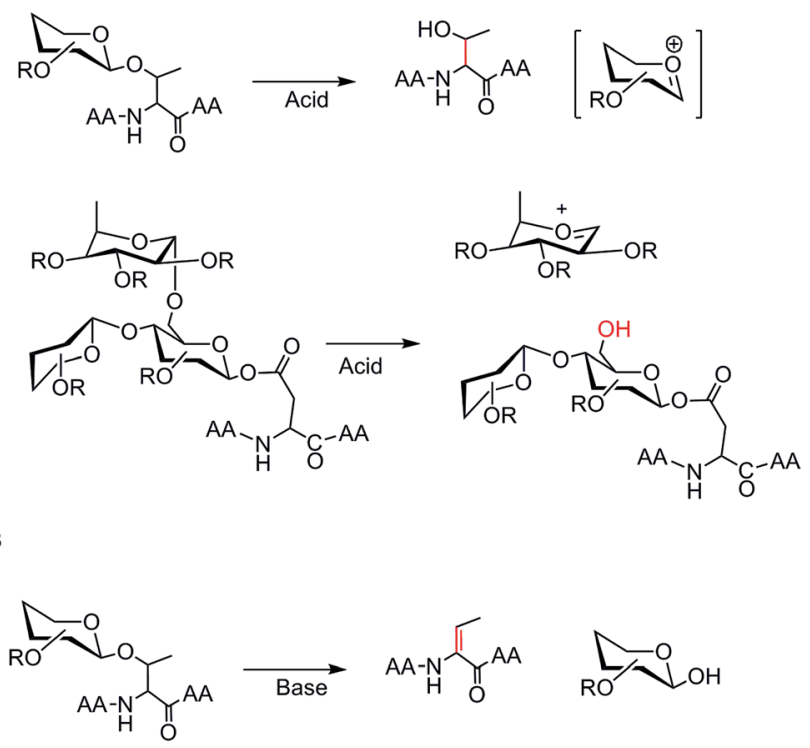

Fig. 7 Chemical lability of glycopeptides. (A) Acid induced $\beta$-elimination and cleavage of a $\alpha$-fucosyl miety. (B) Base induced $\beta$-elimination. 
which can be an advance on the automatization process. ${ }^{48}$ At this point, the combination of large oligosaccharides structures with peptide sequences has been recently automated by Seeberger and coworkers. ${ }^{49}$

\subsection{Lipidated peptides}

In Nature, the lipidation occurs in cysteine or the N-terminal position of the last amino acid. Prenylation (incorporation of farnesyl or geranyl groups) as thioether and palmitoylation as thioester commonly goes to cysteine whereas myristoylation is naturally incorporated on the N-terminus as amide (Fig. 5).

The prenylated groups are quite sensitive to acids (e.g. $\geq 1 \%$ TFA), in particular of the stereochemistry of the double bonds, which are all trans in farnesyl or geranyl groups. The thioester group formed in palmitoylation is quite sensitive to bases, e.g. to piperidine (typical base used in SPPS), but is stable to acidic conditions used in deprotection and resin-cleavage.

Therefore, the solid-phase approach for synthesis of lipidated peptides depends on the lipidated groups. The optimal linker must be stable to acids and bases, being compatible with the presence of lipid, with a mild non acidic cleavage condition and versatile accepting different nucleophiles for cleavage. This versatility permits the introduction of additional reporter groups (e.g. fluorophores, biotin) and to synthesize the desired peptides as carboxylic acids, amides or esters (depending on the precise structure of the natural blueprint, e.g. in Ras proteins as methyl esters).

Thus, the hydrazide linker and the Ellmann alkanesulfonamide linker have been described as two good alternatives for the preparation of these complex and valuable molecules, ${ }^{27,28}$ although Wang, chloride trityl or Rink resins have been employed in the preparation of peptides containing palmitoyl, myristoyl or other lipidated groups..$^{50,51}$

The use of lipidated amino acid building blocks, for non $\mathrm{N}$ terminal modifications, is mandatory in lipidated peptide synthesis. ${ }^{25}$ The direct incorporation of the lipid on resin requires a large excess of lipidation reagent to ensure a complete modification complicating the final purification. It is not readily automatable, and is not suitable for the preparation of longer peptides.

In the case of the presence of thioesters in the lipopeptide, such as palmitoylated cysteine, a very fast removal of the Fmoc group $(1 \% \mathrm{DBU}, 2 \times 30 \mathrm{~s})$ and an immediate coupling of the next preactivated amino acid (employing HATU) in $\mathrm{CH}_{2} \mathrm{Cl}_{2}-$ DMF $4: 1$ has to be carried out to avoid the rapid $S, N$-acyl shift (Fig. 8). ${ }^{27}$ After the incorporation of the palmitoyl thioester on the peptide sequence, collidine must be used as a base. ${ }^{27}$

Consequently, taking into account these important requirements, successful results have been found in the synthesis of Ras family C-terminal tailor-made peptides, incorporating partial or full posttranslational modifications, fluorescent or reporter groups (Fig. 9A). These molecules have been of exceptional value to elucidate biological implications and mechanisms of these proteins. ${ }^{8,36,52,53}$ Also a biotinylated and fluorescent labeled double palmitoylated peptide representing a
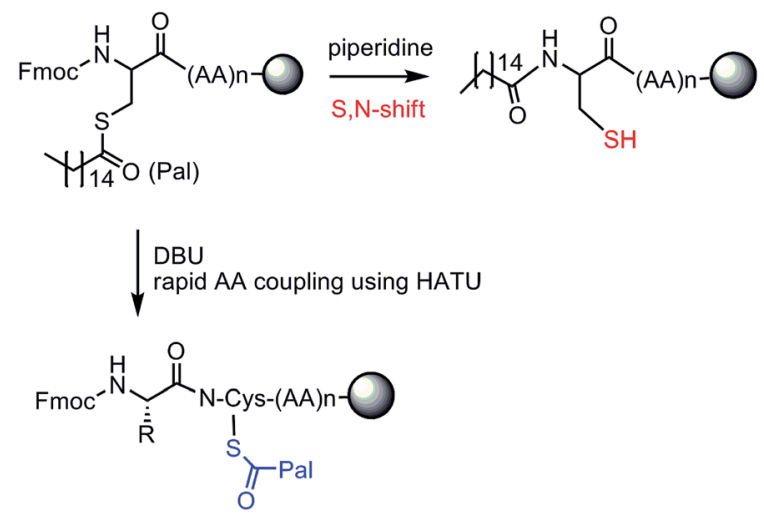

Fig. 8 Elongation of the peptide chain after incorporation of the palmitoylated cysteine.

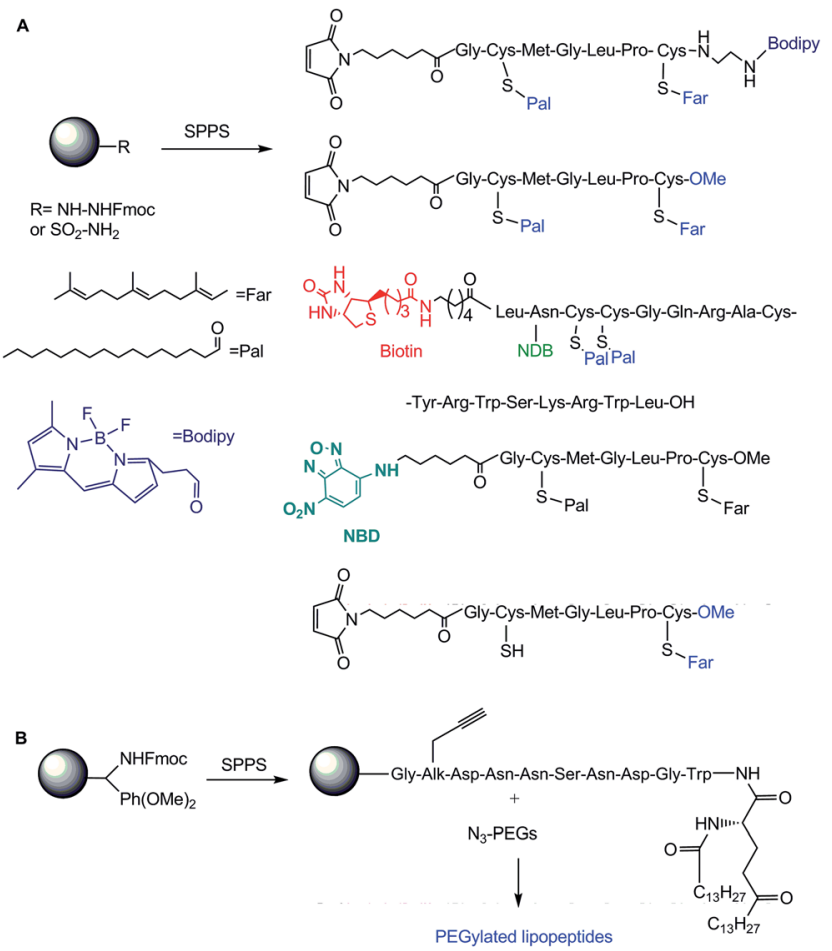

Fig. 9 Solid-phase synthesis of semisynthetic lipidated peptides. (A) Ras and phospholipase mimetic lipopeptides. Ras posttranslational modifications are marked in blue. (B) Synthesis of PEGylated lipopeptides by click chemistry on solid-phase.

characteristic partial structure of phospholipase D has been synthesized at multimilligrams scale by SPPS (Fig. 9A). ${ }^{28}$

Recently new PEGylated lipopeptides have been synthesized on solid phase (with Rink amide resin) by a final click chemistry step between a supported alkyne peptide sequence and an azido-functionalized PEG (Fig. 9B)..$^{50}$ The PEGylation degree depended on the hydrophobicity (lipid chains) of the peptide. This PEGylation permitted to obtain the peptide in a single purification step. These new conjugates could be quite useful in enzymatic activation strategies or liposomal drug delivery. 
Different lipidated-polyarginine peptides ${ }^{51,54}$ have been also successfully synthesized by solid phase technology.

A fragment condensation strategy based on click chemistry has been recently developed by Kunz and coworkers to synthesize new glycolipopeptides as antitumor vaccine candidates. ${ }^{55,56}$ These peptides are composed of MUC1 glycopeptides as the B epitopes and immune-stimulating toll-like receptor2 (TLR2) lipopeptide ligands. For the preparation of these complex molecules, a solid phase strategy was used in each case to synthesizing the N-terminal azide MUC1 glycopeptides using 2chloro-trityl resin and TLR2 lipopeptide with an N-terminally incorporate alkyne group using Wang resin (Fig. 10). ${ }^{55}$ Then both peptides were conjugated by click chemistry in solution (Fig. 10). The biological results demonstrated that these MUC1TLR2-glycolipopeptide elicited immune responses in mice without the use of any external adjuvant. ${ }^{56}$

\section{Synthesis of peptidomimetics}

Peptidomimetics are a new class of synthetic peptides incorporating unnatural amino acids maintaining the structural features of the natural sequences, ${ }^{57-60}$ and have been reported to exhibit comparable or improved biological profiles. ${ }^{61}$ Unnatural amino acids can be prepared from their native analogs by different chemical modifications (e.g. amine alkylation or structural bond extension). ${ }^{57}$ Thus, the different peptidomimetics shown in Fig. 11 have been developed. ${ }^{57}$

Depsipeptides are a class of peptidomimetics where the amino functionality in the amino acid has been substituted by an oxygen atom (Fig. 11) leading to the formation of esters within a peptide backbone. These peptides have been found in Nature with important biological activity such as romidepsin, an anticancer drug, or jaspamide, widespread used in cell biology research as a cell permeable probe of actin dynamics. ${ }^{62}$

Several SPPS strategies have been applied in the preparation of these peptides, (i) where an amino acid and $\alpha$-hydroxy acid
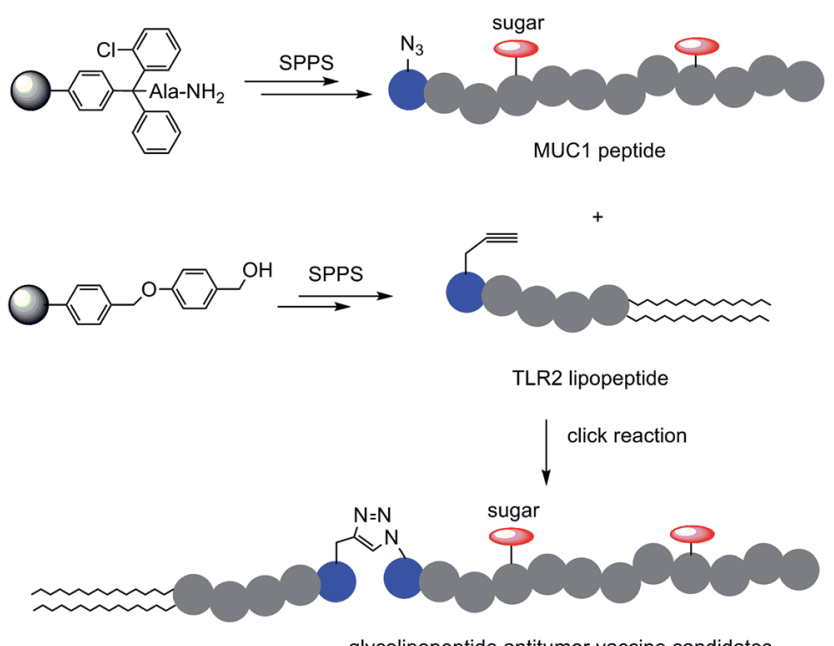

glycolipopeptide antitumor vaccine candidates

Fig. 10 Solid-phase synthesis of antitumor vaccine candidate MUC1TLR2 glycolipopeptide.
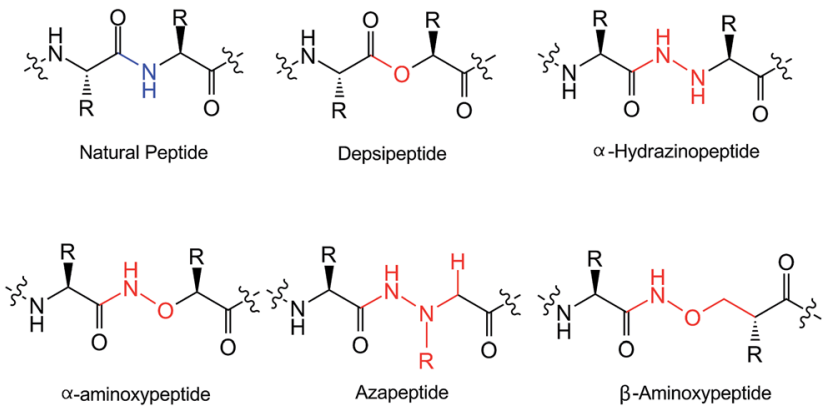

Fig. 11 Different class of peptidomimetics.

building block with an ester bond (prepared in solution) can be coupled via $\mathrm{N}$-acylation on solid phase, or (ii) the condensation of the amino acid and $\alpha$-hydroxy acid on solid phase. Recently a general solid phase method for the synthesis of depsipeptides has been developed alternating esters and amides in the peptide backbone using Fmoc-depsidipeptides building blocks. ${ }^{63}$

The insertion of an extra heteroatom in the peptide backbone by substitution the amino group in the amino acid by a hydrazino (hydrazino acid) or by an aminoxy group (aminoxy acid) permits to synthesize a new class of peptidomimetics (hydrazino or aminoxypeptides) (Fig. 11). They have been synthesized by solid-phase using PEG resins and Boc chemistry. ${ }^{64} \beta$-Aminoxypeptides are another variant, which have an extra carbon atom in the aminoxy backbone.

Aza-peptides are peptidomimetics in which one or more of the R-carbons, bearing the side-chain residues has been replaced by nitrogen (Fig. 11). These peptidomimetics have been shown to be promising for the generation of drug leads and for structure activity relationship studies. For example, Atazanavir, an antiretroviral drug, is a highly active azapeptide inhibitor of the HIV protease. ${ }^{65}$ These peptides have been synthesized on solid phase using Fmoc/t-Bu chemistry. A microwave-assistance approach has been developed to synthesize aza-peptides reducing standard reaction time and is suitable for automation. ${ }^{59}$

Another kind of methodologies using unnatural amino acids to synthesize peptidotriazoles ${ }^{66}$ or $\mathrm{N}$-cycloguanidinyl-formyl peptides $^{67}$ has been recently described.

\section{Preparation of large peptides by fragment condensation approach}

The development of proper strategies to achieve the synthesis of complex peptides on solid phase have permitted to prepare interesting biological applicable peptides as previously described. However, even with these advantages still results difficult to prepare large peptides with lengths of over 60 amino acid residues, which are usually poorly soluble or insoluble, especially when prone to $\beta$-sheet formation. Therefore strategies involving solid phase peptide synthesis followed by insolution fragment coupling have been introduced in order to facilitate the synthesis of large polypeptides. ${ }^{68}$ 
A
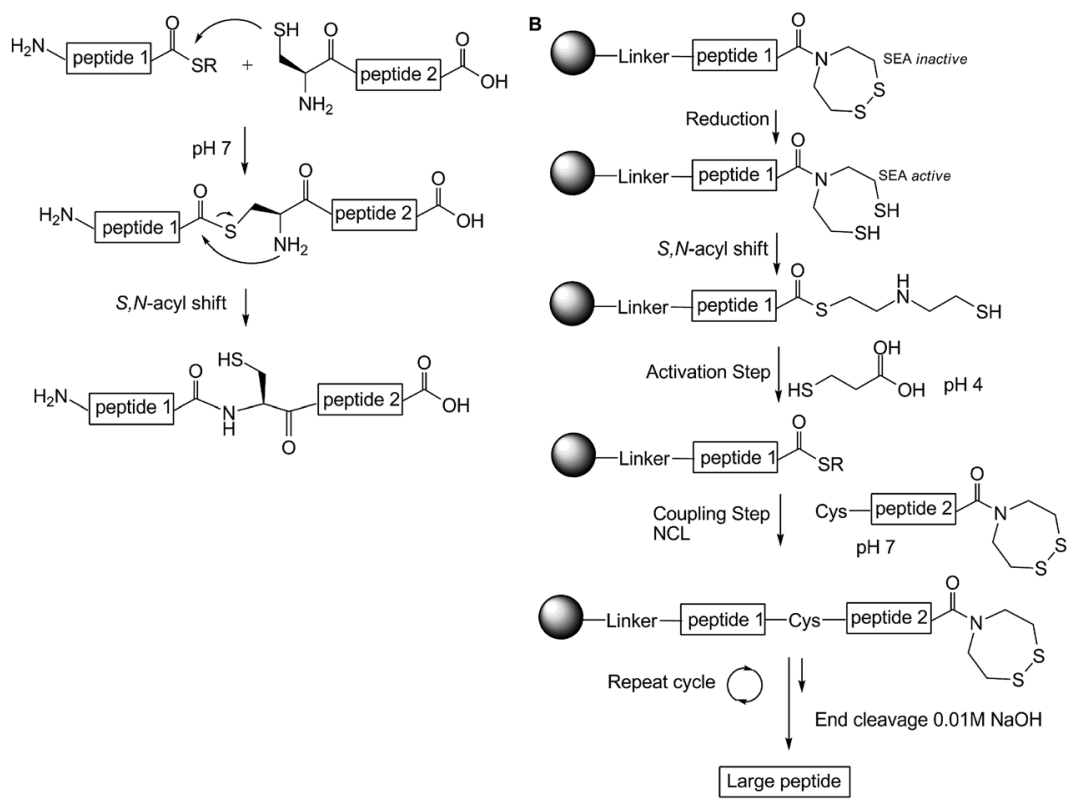

Fig. 12 (A) Classical Native Chemical Ligation (NCL). (B) The N-to-C elongation cycle based on SEA and NCL chemistries on solid-phase.

The most successful method for in solution fragment condensation for chemical synthesis of polypeptides and proteins is native chemical ligation (NCL), reported by Kent for the first time. ${ }^{69}$

NCL is based on the reaction of a C-terminal of a peptide thioester with an $\mathrm{N}$-terminal cysteine containing peptide (Fig. 12a). This reaction proceeds through a thioester-linked intermediate followed by an intramolecular acyl chain migration from sulfur to nitrogen.

This strategy has been successfully applied in the preparation of a large number of polypeptides with different functionalities.

Indeed, variants to the classical NCL, such as using other amino acids instead of cysteine, sequential or kinetically control NCL strategies and the development of NCL on solid phase has been recently developed. ${ }^{70-74}$

In particular, a very efficient solid-phase synthesis of large polypeptides was successfully performed by iterative ligations of bis(2-sulfanylethyl)amido (SEA) peptide segments. ${ }^{73}$

Sequential NCL by the $\mathrm{N}$ to $\mathrm{C}$ elongation cycles between the supported peptide thioester blocked with the SEA group and a free C-terminal thiol group-SEA activated N-terminus peptide (Fig. 12b) permitted to synthesize 60 amino acid-long peptide thioester or to the assembly of five peptide segments to give a 15 kDa polypeptide. ${ }^{73}$

In the same way, $N$-sulfanylethylanilide (SEAlide) activated peptides, as crypto-thioesters, were successfully used for onepot N-to-C-directed ligation under kinetically controlled conditions. The SEAlide unit remains intact under NCL conditions with $\mathrm{N}$-terminal cysteinyl peptides in the absence of phosphate salts, whereas large peptides were synthesized in the presence of phosphate salts (Fig. 12c). This strategy was used by Otaka and coworkers to synthesize a biologically active monoglycosylated GM2-activator protein analogue. ${ }^{74}$

\section{Conclusion}

In this review some important aspects to synthesize complex peptides on solid-phase such as the type of resin, resin swelling, type of linker, protecting groups or deprotection conditions have been discussed. The overview presented in this paper will allow to the reader, being more or less an expert on the subject, to carry out a tailor-made design in the synthesis of a particular peptide by selecting the adequate strategy. Although this is useful to synthesize any peptide sequence, here we focus mainly on the preparation of difficult peptides of high biological interest. For example, the introduction of posttranslational modifications on proteins is not a trivial task and it is essential for application in chemical-biological programs.

Therefore, the value of these tailor-made peptides is the creation of biological relevant semisynthetic proteins by their site-specific incorporation on engineered variants.

Two emerging areas in the preparation of biologically important peptides such as the synthesis of peptidomimetics and the creation of large peptides by fragment condensation strategies have been also emphasized.

Future prospects will be focused on the development of new linkers and new orthogonal protecting groups for a more versatile and highly efficient solid-phase peptide syntheses, making the preparation of complex and longer peptides accessible in higher amounts and in particular to an automatization process.

The availability of an unlimited kit of tailor-made peptide sequences could open the door to the development of new semisynthetic enzymes in many different applications, such as drug synthesis, drug delivery, diseases diagnostic kits, altered biological function in a particular disease, preparation of homogenous vaccines in good yields, etc. 


\section{Declaration of interest}

The authors report no declarations of interest.

\section{Abbreviations}

\begin{tabular}{|c|c|}
\hline AA & Amino acid \\
\hline Ala & Alanine \\
\hline Alloc & Allyloxycarbonyl \\
\hline $\mathrm{AM}$ & Aminomethyl \\
\hline Arg & Arginine \\
\hline Asn & Asparagine \\
\hline Asp & Aspartic acid \\
\hline Boc & tert-Butyloxycarbonyl \\
\hline Cys & Cysteine \\
\hline DBU & 1,8-Diazabicyclo[5.4.0]undec-7-ene \\
\hline DCC & Dicyclohexylcarbodiimide \\
\hline DIC & Diisopropylcarbodiimide \\
\hline DIPEA & $N, N$-Diisopropylethylamine \\
\hline DMF & $N, N$-Dimethylformamide \\
\hline DMSO & Dimethylsulfoxide \\
\hline DTT & Dithiothreitol \\
\hline DVB & Divinylbenzene \\
\hline EDC & $\begin{array}{l}\text { Ethyl-( } N^{\prime}, N^{\prime} \text {-dimethylamino)propylcarbodiimide } \\
\text { hydrochloride }\end{array}$ \\
\hline Far & Farnesyl \\
\hline Fmoc & 9-Fluorenylmethoxycarbonyl \\
\hline Gln & Glutamine \\
\hline Glu & Glutamic acid \\
\hline HATU & $\begin{array}{l}N-\{(\text { Dimethylamino })-1 H-1,2,3 \text {-triazolo }[4,5-b] \text {-pyridino- } \\
\text { 1-ylmethylene }\}-N \text {-methylmethan-aminium } \\
\text { hexafluorophosphate }\end{array}$ \\
\hline HBTU & $\begin{array}{l}N \text {-[(1H-Benzotriazol-1-yl)(dimethylamino)-methylene]- } \\
N \text {-methylmethanaminium hexafluorophosphate } N \text { - } \\
\text { oxide }\end{array}$ \\
\hline $\mathrm{HF}$ & Fluoride hydrogen \\
\hline His & Histidine \\
\hline HOBt & 1-Hydroxybenzotriazole \\
\hline Ile & Isoleucine \\
\hline Lys & Lysine \\
\hline MBHA & 4-Methylbenzhydrylamine \\
\hline Met & Methionine \\
\hline Mtt & 4-Methyltrityl \\
\hline Muc & Mucin \\
\hline Myr & Myristoyl \\
\hline NMP & 1-Methylpyrrolidin-2-one \\
\hline Pal & Palmitoyl \\
\hline $\mathrm{Pbf}$ & Pentamethyl-2,3-dihydrobenzofuran-5-sulfonyl \\
\hline Pmc & 2,2,5,7,8-Pentamethylchroman-6-sulfonyl \\
\hline PEG & Polyethyleneglycol \\
\hline Pro & Proline \\
\hline PS & Polystyrene \\
\hline PyBOP & $\begin{array}{l}\text { Benzotriazol-1-yl- } N \text {-oxy-tris(pyrrolidino)phosphonium } \\
\text { hexafluorophosphate }\end{array}$ \\
\hline Ser & Serine \\
\hline SPPS & Solid-phase peptide synthesis \\
\hline $\mathrm{S}^{t} \mathrm{Bu}$ & tert-Butylmercapto \\
\hline${ }^{t} \mathrm{Bu}$ & tert-Butyl \\
\hline
\end{tabular}

$\begin{array}{ll}\text { TFA } & \text { Trifluoroacetic acid } \\ \text { TFMSA } & \text { Trifluoromethanesulfonic acid } \\ \text { TFFH } & \text { Tetramethylfluoroformamidinium } \\ & \text { hexafluorophosphate } \\ \text { Thr } & \text { Threonine } \\ \text { TMP } & \text { Trimethylpyridine } \\ \text { Trp } & \text { Tryptophan } \\ \text { Trt } & \text { Trityl } \\ \text { Tyr } & \text { Tyrosine } \\ \text { TIS } & \text { Triisopropylsilane } \\ \text { TES } & \text { Triethylsilane }\end{array}$

\section{Acknowledgements}

This work has been sponsored by the Spanish National Research Council (CSIC). I would like to express my sincere gratitude to Mrs Tanya Shew, professional freelance English translator, for the language proofreading of this manuscript.

\section{References}

1 E. Fischer and E. Fourneau, Ber. Dtsch. Chem. Ges., 1901, 34, 2868.

2 M. Bergmann and L. Zervas, Ber. Dtsch. Chem. Ges., 1932, 65, 1192.

3 V. Du Vigneaud, C. Ressler, J. M. Swan, C. W. Roberts, P. G. Katsoyannis and S. Gordon, J. Am. Chem. Soc., 1953, 75, 4879.

4 (a) S. B. H. Kent, Angew. Chem., Int. Ed., 2013, 52, 1198811996; (b) P. Siman and A. Brik, Org. Biomol. Chem., 2012, 10, 5684; (c) O. Romero, M. Filice, B. de las Rivas, C. Carrasco-Lopez, J. Klett, A. Morreale, J. A. Hermoso, J. M. Guisan, O. Abian and J. M. Palomo, Chem. Commun., 2012, 72, 9053; (d) J. Zhu, Q. Wan, D. Lee, G. Yang, M. Spassova, O. Ouerfelli, G. Ragupathi, P. Damani, P. O. Livingston and S. J. Danishefsky, J. Am. Chem. Soc., 2009, 131, 9298.

5 (a) H. J. Rideout and L. Stefanis, Neurochem. Res., 2014, 39, 576; (b) R. Schulz and U. M. Moll, Curr. Opin. Oncol., 2014, 26, 108; (c) C. Nguyen, R. W. Haushalter, D. J. Lee, P. R. L. Markwick, J. Bruegger, G. Caldara-Festin, K. Finzel, D. R. Jackson, F. Ishikawa, B. O'Dowd, J. A. McCammon, S. J. Opella, S.-C. Tsai and M. D. Burkart, Nature, 2014, 505, 427.

6 G. Walsh and R. Jefferis, Nat. Biotechnol., 2006, 24, 1241.

7 I. V. Thiel1, G. Volkmann1, S. Pietrokovski and H. D. Mootz, Angew. Chem., Int. Ed., 2014, 53, 1306.

8 K. Gormer, M. Burger, J. A. W. Kruijtzer, I. Vetter, N. Vartak, L. Brunsveld, P. I. H. Bastiaens, R. M. J. Liskamp, G. Triola and H. Waldmann, ChemBioChem, 2012, 13, 1017.

9 S. B. H. Kent, Chem. Soc. Rev., 2009, 38, 338.

10 R. B. Merrifield, J. Am. Chem. Soc., 1963, 85, 2149.

11 R. B. Merrifiled, Angew. Chem., Int. Ed., 1985, 24, 799.

12 S. L. Pedersen, A. P. Tofteng, L. Malik and K. J. Jensen, Chem. Soc. Rev., 2012, 41, 1826.

13 A. El-Faham and F. Albericio, Chem. Rev., 2011, 111, 6557. 
14 R. Subirós-Funosas, S. N. Khattab, L. Nieto-Rodríguez, A. ElFaham and F. Albericio, Aldrichimica Acta, 2013, 46, 21.

15 (a) M. Schnolzer, P. Alewood, A. Jones, D. Alewood and S. B. H. Kent, Int. J. Pept. Protein Res., 1992, 22, 57; (b) R. B. Merrifield, Science, 1986, 232, 341.

16 L. A. Carpino and G. Y. Han, J. Am. Chem. Soc., 1970, 92, 5748.

17 Fmoc Solid Phase Peptide Synthesis, A Practical Approach, ed. W. C. Chan and P. D. White, Oxford University Press, 2000.

18 I. Coin, M. Beyermann and M. Bienert, Nat. Protoc., 2007, 12, 3247.

19 (a) E. Kaiser, R. L. Colescot, C. D. Bossinge and P. I. Cook, Anal. Biochem., 1970, 34, 595; (b) V. K. Sarin, S. B. H. Kent, J. P. Tam and R. B. Merrifield, Anal. Biochem., 1981, 117, 147.

20 S. L. Snyder and P. Z. Sobocinski, Anal. Biochem., 1975, 64, 284.

21 T. Vojkovsky, J. Pept. Res., 1995, 8, 236.

22 (a) R. De Marco, A. Tolomelli, A. Greco and L. Gentilucci, ACS Sustainable Chem. Eng., 2013, 1, 566; (b) M. Kim, Y.-S. Park, D.-S. Shin, S. Lee and Y.-S. Lee, Tetrahedron Lett., 2012, 53, 4576.

23 Y. García-Ramos, M. Paridis-Bas, J. Tulla-Puche and F. Albericio, J. Pept. Sci., 2010, 16, 675.

24 B. Merrifield, Brit. Poly. J., 1984, 16, 173.

25 (a) R. Santini, M. C. Griffith and M. Qi, Tetrahedron Lett., 1998, 39, 8951; (b) M. Baumann, I. R. Baxendale, S. V. Ley, N. Nikbin and C. D. Smith, Org. Biomol. Chem., 2008, 6, 1587.

26 G. A. Acosta, M. Del Fresno, M. Paradis-Bas, M. RigauDeLlobet, S. Côté, M. Royo and F. Albericio, J. Pept. Sci., 2009, 15, 629.

27 G. Kragol, M. Lumbierres, J. M. Palomo and H. Waldmann, Angew. Chem., Int. Ed., 2004, 43, 5839.

28 (a) G. Triola, M. Gerauer, K. Gormer, L. Brunsveld and H. Waldmann, Chem.-Eur. J., 2010, 16, 9585; (b) J. M. Palomo, M. Lumbierres and H. Waldmann, Angew. Chem., Int. Ed., 2006, 45, 477.

29 S. Wang, J. Am. Chem. Soc., 1973, 95, 1328.

30 H. Rink, Tetrahedron Lett., 1987, 28, 3787.

31 V. Castro, H. Rodriguez and F. Albericio, Org. Lett., 2013, 15, 246.

32 A. Isidro-Llobet, M. Alvarez and F. Albericio, Chem. Rev., 2009, 109, 2455.

33 R. Subirós-Funosas, L. Nieto-Rodriguez, K. J. Jensen and F. Albericio, J. Pept. Sci., 2013, 19, 408.

34 T. Michels, R. Dölling, U. Haberkorn and W. Mier, Org. Lett., 2012, 14, 5218.

35 A. S. Gajadhar and F. M. White, Curr. Opin. Biotechnol., 2014, 28, 83; H. Ryšlavá, V. Doubnerová, D. Kavan and O. Vaněk, J. Proteomics, 2013, 92, 80; E. R. Strieter and D. A. Korasick, ACS Chem. Biol., 2012, 7, 52.

36 G. Triola, H. Waldmann and C. Hedberg, ACS Chem. Biol., 2012, 7, 87.

37 D. P. Gamblin, E. M. Scanlan and B. G. Davis, Chem. Rev., 2009, 109, 131.

38 A. Derouiche, C. Cousin and I. Mijakovic, Curr. Opin. Biotechnol., 2012, 23, 585.
39 M. A. Hollingsworth and B. J. Swanson, Nat. Rev. Cancer, 2004, 4, 45.

40 T. W. Rademacher, R. B. Parekh and R. A Dwek, Annu. Rev. Biochem., 1988, 57, 785.

41 (a) M. Broncel, J. A. Falenski, S. C. Wagner, C. P. R. Hackenberger and B. Koksch, Chem.-Eur. J., 2010, 16, 7881; (b) K. B. Højlys-Larsen and K. J. Jensen, Methods Mol. Biol., 2013, 1047, 191.

42 H. Eberhard and O. Seitz, Org. Biomol. Chem., 2008, 6, 1349.

43 K. B. Højlys-Larsen, K. K. Sørensen, K. J. Jensen and S. Gammeltoft, Mol. BioSyst., 2012, 8, 1452.

44 N. Gaidzik, U. Westerlind and H. Kunz, Chem. Soc. Rev., 2013, 42, 4421.

45 T. Buskas, S. Ingale and G. J. Boons, Glycobiology, 2006, 16, 113R.

46 M. C. Galan, P. Dumy and O. Renaudet, Chem. Soc. Rev., 2013, 42, 4599.

47 M. Bejugam and S. L. Flitsch, Org. Lett., 2004, 6, 4001.

48 B. Liu, F. Zhang, Y. Zhang and G. Liu, Org. Biomol. Chem., 2014, 12, 1892.

49 M. Hurevich and P. H. Seeberger, Chem. Commun., 2014, 50, 1851.

50 R. I. Jølck, R. H. Berg and T. L. Andresen, Bioconjugate Chem., 2010, 21, 807.

51 A. Liberska, A. Lilienkampf, A. Unciti-Broceta and M. Bradley, Chem. Commun., 2011, 47, 12774.

52 O. Rocks, M. Gerauer, N. Vartak, S. Koch, Z. Huang, M. Pechlivanis, J. Kuhlmann, L. Brunsveld, A. Chandra, B. Ellinger, H. Waldmann and P. I. H. Bastiaens, Cell, 2010, 141, 458.

53 C. Nicolini, J. Baranski, S. Schlummer, J. Palomo, M. Lumbierres-Burgues, M. Kahms, J. Kuhlmann, J. Sanchez, E. Gratton, H. Waldmann and R. Winter, J. Am. Chem. Soc., 2006, 128, 192.

54 A. Schieck, T. Müller, A. Schulze, U. Haberkorn, S. Urban and W. Mier, Molecules, 2010, 15, 4773.

55 H. Cai, Z.-H. Huang, L. Shi, Y.-F. Zhao, H. Kunz and Y.-M. Li, Chem.-Eur. J., 2011, 17, 6396.

56 H. Cai, Z.-Y. Sun, M.-S. Chen, Y.-F. Zhao, H. Kunz and Y.-M. Li, Angew. Chem., Int. Ed., 2014, 53, 1699.

57 I. Avan, C. D. Hall and A. R. Katritzky, Chem. Soc. Rev., 2014, 43, 3575 .

58 K. S. Agrawal, P. Panini, M. Sathe, D. Choprab and M. P. Kaushika, RSC Adv., 2014, 4, 10728.

59 N. S. Freeman, Y. Tal-Gan, S. Klein, A. Levitzki and C. Gilon, J. Org. Chem., 2011, 76, 3078.

60 J. H. Lee, H.-S. Kim and H.-S. Lim, Org. Lett., 2011, 13, 5012. 61 R. K. Sharma, S. Sundriyal, N. Wangoo, W. Tegge and R. Jain, ChemMedChem, 2010, 5, 86.

62 G. Kustermans, J. Piette and S. Legrand-Poels, Biochem. Pharmacol., 2008, 76, 1310.

63 M. M. Nguyen, N. Ong and L. Suggs, Org. Biomol. Chem., 2013, 11, 1167.

64 M.-R. Lee, J. Lee, B.-H. Baek and I. Shin, Synlett, 2003, 325. 65 N. von Hentig, Drugs Today, 2008, 44, 103.

66 I. Güell, S. Vilà, L. Micaló, E. Badosa, E. Montesinos, M. Planas and L. Feliu, Eur. J. Org. Chem., 2013, 2013, 4933. 
67 X. Yang, G. Bai, H. Lin and D. Wang, Tetrahedron Lett., 2014, $55,1733$.

68 M. Inoue, N. Shinohara, S. Tanabe, T. Takahashi, K. Okura, H. Itoh, Y. Mizoguchi, M. Iida, N. Lee and S. Matsuoka, Nat. Chem., 2010, 2, 281.

69 P. E. Dawson, T. W. Muir, I. Clark-Lewis and S. B. Kent, Science, 1994, 266, 776.

70 S. S. Panda, C. D. Hall, A. A. Oliferenko and A. R. Katrizky, Acc. Chem. Res., 2014, 47, 1076.
71 J.-C. M. Monbaliu and A. R. Katritzky, Chem. Commun., 2012, 48, 11601.

72 P. M. Levine, T. W. Craven, R. Bonneaub and K. Kirshenbaum, Org. Biomol. Chem., 2013, 11, 4142.

73 L. Raibaut, H. Adihou, R. Desmet, A. F. Delmas, V. Aucagne and O. Melnyk, Chem. Sci., 2013, 4, 4061.

74 K. Sato, A. Shigenaga, K. Kitakaze, K. Sakamoto, D. Tsuji, K. Itoh and A. Otaka, Angew. Chem., Int. Ed., 2013, 52, 7855. 